\title{
Imported dengue from 2013 Angola outbreak: Not just serotype 1 was detected
}

\author{
Cândida Abreu ${ }^{\mathrm{a}, \mathrm{b}, *, 1}$, André Silva-Pinto ${ }^{\mathrm{a}, 1}$, Daniela Lazzara ${ }^{\mathrm{c}}$, Joana Sobrinho-Simões ${ }^{\mathrm{c}}$, \\ João Tiago Guimarães ${ }^{c, d}$, António Sarmento ${ }^{a, b}$ \\ a Department of Infectious Diseases, Centro Hospitalar S. João, Porto, Portugal \\ b Instituto de Inovação e Investigação em Saúde (I3S), Grupo de IED em Nefrologia e Doenças Infecciosas, Instituto Nacional de Engenharia Biomédica \\ (INEB), Portugal \\ ' Clinical Pathology Service, Centro Hospitalar S. João, Portugal \\ ${ }^{\mathrm{d}}$ EPIUnit, Institute of Public Health, University of Porto, Portugal
}

\section{A R T I C L E I N F O}

\section{Article history:}

Received 28 December 2015

Received in revised form 11 April 2016

Accepted 13 April 2016

\section{Keywords:}

Dengue

Angola

Angola's dengue outbreak

Dengue serotype

\begin{abstract}
A B S T R A C T
Background: All the reports from Angola's 2013 dengue outbreak revealed serotype 1. However, previously dengue serotypes 1-4 have been reported in Africa and in 2014 serotype 4 was reported in Angola. Objectives: To report dengue serotypes in patients returning from Angola during 2013 outbreak.

Study design: Retrospective, cross-sectional study. We serotyped the dengue by an in house Polymerase Chain Reaction technique in randomly selected cases.

Results: From the 2013 Angola's dengue outbreak we treated 47 adult patients. None had history of past dengue. A combo kit test for dengue revealed positive NS1 antigen in 39 and IgM antibodies in 8. From 17 randomly patients tested by RNA Real Time-PCR, 11 were positive: 7 for DENV-1, 2 for DENV-2, 1 for DENV-3 (co-infected with DENV-1) and 1 for DENV-4. None had a complicated or fatal evolution.

Conclusion: Unlike previous reports the 4 serotypes were detected, and this resulted in a different epidemiological situation, raising the risk of future outbreaks of severe dengue.
\end{abstract}

(c) 2016 Elsevier B.V. All rights reserved.

\section{Background}

Serosurveys in Africa document the presence of dengue since 1926 [1]. In Africa the surveillance data are poor and its knowledge is not accurate [2]. Despite this, there are reports from serotypes 1 , 2, 3 and, more rarely, serotype 4 in several African countries [3-6].

Angola's dengue cases have been described in 1986 and 1999-2002 [7], but no dengue outbreak was reported until 2013. All isolates from this outbreak have been consistently reported as serotype 1 [8-10]. However, in 2014 Parreira et al. published a case report of a co-infection of serotype 4 dengue and Chikungunya virus imported from Angola [11].

\footnotetext{
* Corresponding author at: Centro Hospitalar São João, Department of Infectious Diseases Alameda Hernâni Monteiro, 4200 Porto, Portugal.

E-mail address: candida.abreu@gmail.com (C. Abreu).

1 These two authors contributed equally in the design, conception, analysis, and paper writing.
}

\section{Objectives}

To report clinical and laboratory data concerning imported dengue in 2013 in patients returning from Angola.

\section{Methods}

We made a hospital-based, retrospective and cross-sectional study, analysing all the clinical and laboratory records of adults returning from Angola and diagnosed with dengue. We used an in-vitro rapid immunochromatographic assay, SD BIOLINE Dengue Duo $^{\circledR}$ (Dengue NS1 Ag+IgG/IgM) kit following the manufacture protocol. From some randomly selected patients the plasma was frozen $\left(-20^{\circ} \mathrm{C}\right)$. Later we tested for Dengue virus RNA and serotyped. We used an in-house one step Reverse Transcription Real Time Polymerase Chain Reaction (RT-PCR) test with primers and probes described by Laue et al. [12]. All samples were tested separately with each of the four primers/probe sets. One step RTPCR Kit (Qiagen ${ }^{\circledR}$ ) with Q-solution was used with primers and probes described with a final $50 \mu$ l reaction with $10 \mu$ l of RNA extracted plasma sample (EZ1 RNA virus mini-kit, Qiagen ${ }^{\circledR}$ ) or water for negative control. We used a real-time thermocycler 
Table 1

Laboratory dengue diagnosis.

\begin{tabular}{|c|c|c|c|}
\hline Dengue Combo Test & NS1 atg positive & IgM + IgG positive & Total \\
\hline Isolated NS1 atg positive & 27 & - & 27 \\
\hline IgM positive & 6 & - & 6 \\
\hline Ig M + Ig G positive & 6 & 8 & 14 \\
\hline TOTAL & 39 & 8 & 47 \\
\hline
\end{tabular}

Table 2

Dengue serotype determination combined with dengue Test results and demographic data.

\begin{tabular}{|c|c|c|c|c|c|c|c|}
\hline Gender & Age (years) & Time from fever onset to test (days) & NS1 & $\operatorname{IgM}$ & $\operatorname{IgG}$ & RT-PCR & Co-infections \\
\hline Male & 59 & 1 & + & - & - & DENV-1 & None \\
\hline Male & 44 & 5 & + & - & - & DENV-1 and DENV-3 & None \\
\hline Male & 38 & 1 & + & - & - & DENV-1 & None \\
\hline Male & 41 & 5 & + & + & - & DENV-2 & None \\
\hline Female & 51 & 4 & + & + & - & DENV-1 & HIV-1 \\
\hline Female & 37 & 7 & + & + & + & DENV-1 & None \\
\hline Male & 26 & 1 & + & - & - & DENV-1 & None \\
\hline Male & 34 & 5 & + & + & + & DENV-2 & None \\
\hline Female & 28 & 2 & + & - & - & DENV-1 & None \\
\hline Female & 53 & 9 & - & + & + & DENV-4 & None \\
\hline Male & 32 & 1 & + & - & - & DENV-1 & None \\
\hline Female & 36 & 7 & + & + & + & NEG & None \\
\hline Male & 52 & 5 & + & + & + & NEG & None \\
\hline Male & 39 & 7 & + & + & - & NEG & None \\
\hline Male & 41 & 5 & + & + & - & NEG & None \\
\hline Male & 26 & 3 & - & + & + & NEG & Malaria \\
\hline Female & 61 & 2 & - & + & + & NEG & Malaria \\
\hline
\end{tabular}

(Rotor gene 3000, Corbett Research ${ }^{\circledR}$ ) and after a 30-min reverse transcription step at $50^{\circ} \mathrm{C}$ and $15 \mathrm{~min}$ of Taq activation, cDNA was amplified using a two-step protocol with the initial 10 cycles with $56^{\circ} \mathrm{C}$ for annealing temperature and $50^{\circ} \mathrm{C}$ with fluorescence acquisition during the next 35 cycles. The test performance was verified with participation in Quality Control for Molecular Diagnostic (QCMD) 2014 Dengue virus RNA External Quality Assessment (EQA) program (all 4 serotypes were tested in the external control and the results were $100 \%$ concordant). We used negative controls for each sample. All patients were screened for Plasmodium spp. - blood smear and a rapid test (BinaxNOW ${ }^{\circledR}$ Malaria) - and for HIV infection - commercial fourth generation test (Architect ${ }^{\circledR}$ HIV Ag/Ab Combo, Abbott), hepatitis (A, B and C - commercial tests) and typhoid fever (blood cultures).

\section{Results}

From the 47 patients with dengue, 45 were non-Angolan and 20 were expatriate in Angola. No patient had previously reported clinical dengue fever. They all lived or stayed for some days in Luanda, before travelling to Portugal. At diagnosis fever was reported in all patients, myalgia in 40 , headache in 37 , asthenia in 31 , retro-orbital pain in 17 and arthralgia in 15 . Gum bleeding and metrorrhagia was elicited in 2 patients.

\subsection{Laboratory data}

Diagnosis was based on NS1 antigenaemia and/or Dengue IgM positivity (Table 1). A dengue virus RT-PCR in-house was performed in 17 patients (Table 2). All four dengue serotypes were detected: 7 for DENV-1, 2 for DENV-2, 1 for DENV-3 (co-infected with DENV-1) and 1 for DENV-4 (Table 2). Amongst the six patients with RT-PCR in-house negative test, four were NS1 antigen positive.

\subsection{Co-infections}

In two patients, malaria and dengue were simultaneously diagnosed. The blood smear was positive for Plasmodium (para- sitaemia < 1\%) and antigen test revealed $P$. falciparum. One man expatriated in Luanda was under treatment for HIV infection, having an undetectable viral load and CD4 lymphocytes count of 600 cells $/ \mathrm{mm}^{3}$. Evolution was unremarkable in these three patients.

\subsection{Outcome}

Clinical outcome was good for all the 47 patients.

Prolonged asthenia was reported in 12 patients, headache, insomnia and itching in 2 each, transitorily arthralgia and dysesthesia in one each.

\section{Discussion}

This study addresses for the first time the circulation of the four dengue serotypes in the 2013 Angola's outbreak. The outbreak was linked to serotype 1 [8]. In Africa very few studies explore the serotypes identification, evolutionary history and dynamic of the disease and there is not any report of these serotypes co-circulating [13]. The detection of the four serotypes in this outbreak may translate a large dissemination of dengue virus.

We screened all the samples with the SD BIOLINE Dengue Duo ${ }^{\circledR}$ kit following the manufacture protocol and the diagnosis was based on NS1 antigenaemia and/or Dengue IgM positivity. We also performed a dengue virus RT-PCR in 17 patients. We tested only 17 samples because we did not have samples from all the patients, as this was a retrospective study. The RT-PCR was previously tested and verified by an external Quality Assessment Program (Quality Control for Molecular Diagnostic (QCMD) 2014 Dengue virus RNA). This program is accredited to ILAC-G13:08/2007/ISO/IEC Guide 4396 01:1997 (ISO17043:2010) and is also ISO9001:2008 certified. For all of these reasons we believed that the results that we found in this cohort are real. Although we did not have the opportunity to appreciate the real dimension of these results because we did not have access to more samples from this outbreak. Four of the seventeen positive's patients sample for NS1 antigen had negative serotype determination. This can be easily understood when we look at the kinetics of the antigenemia and viremia [2]. Six 
Portuguese patients were antigen NS1 and Ig M plus IgG positive; 3 of them were living in Angola for more than 2 years, although none of them has past clinical history of dengue.

At that time (2013) the Chikungunya and Zika virus tests were not available in our hospital, so none of our patients was tested for these virus. Besides, co-infection with Chikungunya in Angola was reported only in the following year [11]. In 2013, neither we knew Zika virus widespread distribution [14] nor its clinical implications $[15,16]$ and no case has yet been reported in Angola. Because of this facts, we were not so aware of possible co-infection with dengue or Zika virus infection at that time. Apart from this, clinically the symptoms suggested dengue fever, as patients had no conjunctivitis or relevant arthralgia.

The relevance of urban growth, travel, migration, and commercial trade in the spread of dengue and in the introduction of new dengue serotypes cannot be missed. Portugal may be a gate for dengue dissemination in Southern Europe, considering the close relationship with several sub-Saharan African countries and the rapid spreading and establishing of the vector $A$. albopictus, already presented in Spain [17]. Co-circulation of all dengue serotypes may predispose infected individuals to Dengue hemorrhagic fever in infection by a different serotype. Studies that address the issue of concomitant circulation of multiple dengue virus serotypes in this outbreak are welcome. Closely monitoring the ongoing Dengue cases and spread of the virus type in Africa is essential to understand the dynamic and the global burden of disease.

\section{Acknowledgements}

The authors would like to thank Professor Henrique Lecour for his valuable comments and review of the draft manuscript.

\section{References}

[1] R.H. Kokernot, K.C. Smithburn, M.P. Weinbren, Neutralizing antibodies to arthropod-borne viruses in human beings and animals in the Union of South Africa, J. Immunol. 77 (1956) 313-323.

[2] WHO/TDR, Dengue Guidelines for Diagnosis, Treatment, Prevention and Control, New edition, World Health Organization, Geneva, 2009.

[3] M. Caron, C. Paupy, G. Grard, P. Becquart, I. Mombo, B.B. Nso, F. Kassa, D. Nkoghe, E.M. Leroy, Recent introduction and rapid dissemination of Chikungunya virus and Dengue virus serotype 2 associated with human and mosquito coinfections in Gabon, central Africa, Clin. Infect. Dis. 55 (2012) e45-53.
[4] L. Franco, G. Palacios, J.A. Martinez, A. Vazquez, N. Savji, F. De Ory, M.P. Sanchez-Seco, D. Martin, W.I. Lipkin, A. Tenorio, First report of sylvatic DENV-2-associated dengue hemorrhagic fever in West Africa, PLoS Negl. Trop. Dis. 5 (2011) e1251.

[5] P. Gautret, F. Simon, H. Hervius Askling, O. Bouchaud, I. Leparc-Goffart, L. Ninove, P. Parola, Dengue type 3 virus infections in European travellers returning from the Comoros and Zanzibar, February-April 2010, Euro Surveill. 15 (2010) 19541

[6] M.L. Moi, M. Ujiie, T. Takasaki, I. Kurane, Dengue virus infection in travellers returning from Benin to France, July-August, 2010, Euro Surveill. 15 (2010) 19674.

[7] A. Amarasinghe, J.N. Kuritsk, G.W. Letson, H.S. Margolis, Dengue virus infection in Africa, Emerg. Infect. Dis. 17 (2011) 1349-1354.

[8] R. Parreira, C. Conceicao, S. Centeno-Lima, N. Marques, J. Saraiva da Cunha, C. Abreu, L. Sa, A. Sarmento, J. Atouguia, V. Moneti, T. Azevedo, J. Nina, K. Mansinho, A. Antunes, R. Teodosio, T. Nazareth, J. Seixas, Angola's 2013 dengue outbreak: clinical: laboratory and molecular analyses of cases from four Portuguese institutions, J. Infect. Dev. Ctries. 8 (2014) 1210-1215.

[9] E. Schwartz, E. Meltzer, M. Mendelson, A. Tooke, F. Steiner, P. Gautret, B. Friedrich-Jaenicke, M. Libman, H. Bin, A. Wilder-Smith, D. Gubler, D.O. Freedman, P. Parola, Detection on four continents of dengue fever cases related to an ongoing outbreak in Luanda, Angola, March to May 2013, Euro Surveill. 18 (2013).

[10] O.M. Sessions, K. Khan, Y. Hou, E. Meltzer, M. Quam, E. Schwartz, D.J. Gubler, A. Wilder-Smit, Exploring the origin and potential for spread of the 2013 dengue outbreak in Luanda, Angola, Glob. Health Action 6 (21822) (2013).

[11] R. Parreira, S. Centeno-Lima, A. Lopes, D. Portugal-Calisto, A. Constantino, J. Nina, Dengue virus serotype 4 and chikungunya virus coinfection in a traveller returning from Luanda, Angola, January 2014, Euro Surveill. 19 (2014).

[12] T. Laue, P. Emmerich, H. Schmitz, Detection of dengue virus RNA in patients after primary or secondary dengue infection by using the TaqMan automated amplification system, J. Clin. Microbiol. 37 (1999) 2543-2547.

[13] J.P. Messina, O.J. Brady, T.W. Scott, C. Zou, D.M. Pigott, K.A. Duda, S. Bhatt, L. Katzelnick, R.E. Howes, K.E. Battle, C.P. Simmons, S.I. Hay, Global spread of dengue virus types: mapping the 70 year history, Trends Microbiol. 22 (2014) $138-146$.

[14] R. Zwizwai, Infection disease surveillance update, Lancet Infect. Dis. 16 (2016) 415.

[15] N. Broutet, F. Krauer, M. Riesen, A. Khalakdina, M. Almiron, S. Aldighieri, M. Espinal, N. Low, C. Dye, Zika virus as a cause of neurologic disorders, N. Engl. J. Med. (2016), http://dx.doi.org/10.1056/nejmp1602708.

[16] G. Carteaux, M. Maquart, A. Bedet, D. Contou, P. Brugieres, S. Fourati, L. Cleret de Langavant, T. de Broucker, C. Brun-Buisson, I. Leparc-Goffart, A. Mekontso Dessap, Zika virus associated with meningoencephalitis, N. Engl. J. Med. (2016), http://dx.doi.org/10.1056/nejmc1602964.

[17] L. Lambrechts, T.W. Scott, D.J. Gubler, Consequences of the expanding global distribution of Aedes albopictus for dengue virus transmission, PLoS Negl. Trop. Dis. 4 (2010) e646. 